This item was submitted to Loughborough's Research Repository by the author.

Items in Figshare are protected by copyright, with all rights reserved, unless otherwise indicated.

\title{
Human rights, globalization and sentimental education: the case of sport
}

PLEASE CITE THE PUBLISHED VERSION

http://dx.doi.org/10.1080/1743043042000291686

PUBLISHER

(C) Taylor \& Francis

VERSION

AM (Accepted Manuscript)

LICENCE

CC BY-NC-ND 4.0

REPOSITORY RECORD

Giulianotti, Richard. 2019. "Human Rights, Globalization and Sentimental Education: The Case of Sport". figshare. https://hdl.handle.net/2134/15504. 
This item was submitted to Loughborough's Institutional Repository (https://dspace.lboro.ac.uk/) by the author and is made available under the following Creative Commons Licence conditions.

\section{creative
commons}

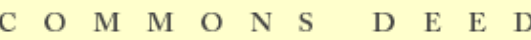

Attribution-NonCommercial-NoDerivs 2.5

You are free:

- to copy, distribute, display, and perform the work

Under the following conditions:

Attribution. You must attribute the work in the manner specified b the author or licensor.

Noncommercial. You may not use this work for commercial purposes.

No Derivative Works. You may not alter, transform, or build upon this work.

- For any reuse or distribution, you must make clear to others the license terms of this work.

- Any of these conditions can be waived if you get permission from the copyright holder.

Your fair use and other rights are in no way affected by the above.

This is a human-readable summary of the Leqal Code (the full license).

\section{Disclaimer 만}

For the full text of this licence, please go to: http://creativecommons.org/licenses/by-nc-nd/2.5/ 


\title{
Human Rights, Globalization and Sentimental Education: The Case of Sport
}

\author{
Richard Giulianotti \\ This is a copy of the Author's Original Text of an article whose final and definitive from, the \\ Version of Record, has been published in Sport in Society: Cultures, Commerce, Media, Politics \\ [copyright Taylor and Francis], DOI: 10.1080/1743043042000291686
}

To Cite: Giulianotti, R., (2004) Human Rights, Globalization and Sentimental Education: The Case of Sport, Sport in Society: Cultures, Commerce, Media, Politics, 7:3, 355-369.

Published Version Available At:

http://www.tandfonline.com/doi/abs/10.1080/1743043042000291686\#.U3E2L ldV8E

In February 2003, the United Nations, the Swiss Agency for Development and Cooperation, and the Swiss Federal Office of Sports, convened an international conference on 'Sport and Development' that was held in Magglingen, Switzerland. Over 380 conference delegates from 55 nations were in attendance, representing governmental bodies, the United Nations system, athletes, sports organizations, non-governmental organizations (NGOs), scientific research institutes, and media corporations. The conference followed at least two others that had spotlighted sport, human rights and development issues. ${ }^{1}$ The Magglingen convention, however, brought a fresh political impetus to the sports-human rights relationship. The chairpersons of the various conference sessions reported the conclusions that had emerged; these points were incorporated within the 'Magglingen Declaration and Recommendations', a document that was submitted in turn to the United Nations for implementation.

The hosting of these conventions has certainly been inspired by the belief of international organizations that sport may be utilized to achieve positive social outcomes. According to the Red Cross in Indo-China, 'Sport transforms men and women by endowing them with strength, endurance, vivacity and courage'. For the United Nations High Commission for Refugees (UNHCR), Sadako Ogata said, 'Sports and recreation are vital for all children. For a refugee child they are irreplaceable in helping rebuild a destroyed world.' The Secretary-General of the United Nations now has a Special Adviser on Sport for Development and Peace. According to the current incumbent, Adolf Ogi, a former President of Switzerland:

Sport teaches life skills. Sport remains the best school of life. With sport, young people learn: to manage victory; to overcome defeat; to become team 
players and to be reliable and gain the other team members' confidence; respect for opponents and the rules; that for good results regular training is needed; and, to know their limits and themselves better. The positive lessons and values of sport are essential for life. ${ }^{2}$

Driven by these convictions, numerous international organizations have introduced various forms of sport-related work to promote peace, development and human dignity. Here are some examples of that work:

1. The International Commission for the Red Cross (ICRC) has employed sports stars to publicise its anti-personnel mines campaign.

2. The ICRC, the International Olympic Committee (IOC), and other international federations have assisted victims of genocide in Rwanda.

3. The International Labour Organization launched its 'Red Card to Child Labour' campaign at the 2002 African Nations Cup finals. In December 2002, the campaign was adopted by Real Madrid, notably for the club's centennial exhibition fixture, generating extensive coverage in the Spanish media.

4. Red Deporte y Cooperación was established in 1999, with headquarters in Madrid and the United States, with the aim of 'educating values and promoting physical, intellectual and psychomotor skills and development amongst underprivileged youth through organized sport activities'. The main beneficiaries of the eight programmes that it runs in South America and sub-Saharan Africa are low income and high risk children and youths as well as specific groups of young women.

5. In Colombia, the Fútbol por la Paz project was established through local sports associations to rehabilitate and reintegrate drug-addicted young people and those caught up in drug trafficking. 6. Partnerships have been established between international federations and humanitarian NGOs, e.g. the IOC and the UNHCR, Fédération Internationale de Football Association (FIFA) and SOS-Children's Villages.

Now, there is no question that some remarkable sports-focused work is being done by NGOs in regard to reconciliation, peace-building, and rehabilitation work. The football schools in the Balkans are a particularly strong illustration. ${ }^{4}$ However, there are some significant problems in any argument that considers sport a priori to be a force for human goodness.

First, the position taken by those such as Adolf Ogi is essentially a functionalist one, in that it assumes that sport meets crucial social needs and is a powerful and positive force for social integration. Of course, there is much historical counter-evidence to suggest that sport can just as 
easily prove far more dysfunctional than functional to social order, in dramatizing or intensifying sources of social conflict, as expressed, for example, through nationalism, sexism, racism and other strains of xenophobia.

Second, in their development and peace work the shift of 'sport evangelists' to locations outside the West may constitute a form of neo-colonial repositioning. Through the twentieth century, sports evangelism at home had sought to promote organized sporting activities to dissipate the lower orders' dangerous energies and to divert them from 'licentious' social practices (such as drinking, gambling, casual sex, and the following of youth subcultural styles). There is little convincing evidence to suggest that such evangelism has proved wholly successful among young people in the West over the years. However, it appears to be assumed, the young people in the old colonies may be more readily organized to receive and internalize the tendentious, selfcontrolling messages buried within sports.

Third, even if we accept for argument's sake that sport is a force for positive transformation, the focus of sporting humanitarianism tends to be heavily skewed towards meeting the needs of young people. My concern is that such prioritization, not least in the allocation of sport resources, is unnecessarily exclusionary towards other social cleavages, notably women and the old.

Fourth, underlying all of these concerns are more fundamental questions regarding the crosscultural politics of sport humanitarianism. Is there sufficient dialogue between the donors and recipients before sports-related aid is offered? Are recipients sufficiently empowered to claim ownership over these projects? Ultimately, what are the complex dynamics of power and meaning behind cross-cultural 'cooperation' between donor and recipient groups?

These problems were uppermost in our minds when we presented our paper to the Magglingen conference. ${ }^{5}$ In line with the conference's remit, our discussion concluded in strongly practical mode by advancing recommendations for the deployment of sport in facilitating peaceful solutions within contexts of war, violence and social crisis. With a few minor emendations, these recommendations were adopted by conference delegates and included within the final declaration.

To summarize these recommendations, we argued for: 
- The expansion of sport programmes in conflict zones, to promote rehabilitation and reconciliation.

- Dialogue between the donors and recipients of aid. Donors must receive the informed consent of recipients, whose members should include women, adults, the old and the disabled.

- Reflection on the role of sports bodies and NGOs in promoting sport's internationalism and humanitarian ethos, and its possible contributions to development. Ties between specific athletes and particular regions should be strengthened.

- Sports bodies and other NGOs to evaluate projects before implementation, and to explore their sustainability and clarify long-term ownership.

- The expansion of connections between NGOs and sports federations.

But all of this required to take place alongside more direct strategies for alleviating famine, warfare, poverty and forced migration.

In this brief discussion of issues relating to sport, human rights and development, I seek to build on these arguments by probing more deeply the kind of concerns raised in the fourth criticism, relating to the political and cross-cultural dimensions of sports projects. The discussion is divided into three main parts. I open by outlining how sport's governing bodies relate to the 1948 Universal Declaration of Human Rights and the rise of a 'culture of rights'. Second, I address the question of cross-cultural difficulties in establishing human rights cultures with reference to critical analysts of globalization. Third, I turn to conceptualize the interrelations between human rights, globalization and humankind with reference to the work of Robertson and Rorty.

\section{Sport, Human Rights and the 1948 Declaration}

The cornerstone of any discussion of human rights must be the 1948 Universal Declaration of Human Rights. The Declaration itself is couched in the highly individualistic terms that are hegemonic within Western liberal democracies. With the very partial exception of Articles 28 and 29, the 30 articles say hardly anything on collective rights, whether in regard to nation-states, international society or humankind. Explicit mention of sport is absent, although Article 24 does insist that 'everyone has the right to rest and leisure', while Article 27 highlights the individual's 'right freely to participate in the cultural life of the community'. 
For developing nations particularly, there is a grim irony in the historical processes that underlie the Declaration. The Western powers 'discovered' these other cultures, enslaved the peoples, expropriated their natural and human resources, and then, once such exploitation had proved too exhausting to maintain, the colonists introduced the colonized to notions of nationhood, political independence, free-market international trading, and human rights. Such hopeful guarantees of human dignity would have been perfectly unnecessary if this cycle of colonization and decolonization had never started in the first place.

A more specific irony lies in sport's historical contribution to the colonial subjugation of nonWestern cultures. Western sports institutions have been directly implicated in acts of cultural genocide. I mean this not only in the more general sense that Western sports were constituent parts of the colonial military-industrial complexes that enslaved or proletarianized whole societies. Rather, and more specifically, cultural genocide arose in the deliberate supplanting of non-Western body cultures with imperial games. ${ }^{6}$ In British imperial outposts, sport was utilized particularly by Christian missionaries and other imperial pedagogues to crush indigenous cultural identities and practices, to set about creating 'a universal Tom Brown: loyal, brave, truthful, a gentleman and, if at all possible, a Christian'?

As one would expect, official institutional discourses within sports organizations rarely encroach upon this dubious (and largely hidden) history. Rather, the official discourses prefer to recognize only those moments of sports-related violence that have been produced by 'enemies' of Western states, such as the Nazis (the 1936 Olympics), Arab terrorists (the 1972 Olympics), or football hooligans (1985 Heysel disaster). ${ }^{8}$

However, far more deadly and far more frequent have been those instances of terrorism or the infringement of fundamental human rights that have been initiated by states which are members of international sports federations and which are at least recognized, if not supported, by the United States and its allies. For example, it is estimated that over 500 demonstrators were murdered by Mexican 'security' forces in what became known as the Tlatelolco Massacre in Mexico City, ten days before the city was permitted to host the Olympic Games. Ten years later, FIFA gifted the World Cup finals to the junta that ruled Argentina, despite the fact that this 'bulwark against regional communism' was proceeding to murder 30,000 people (mainly its own citizens), and to detain and torture tens of thousands more, between 1976 and 1983. ${ }^{9}$ Nor are the developed nations free from critical scrutiny. Prior to the 1982 Commonwealth Games in Brisbane, the Queensland legislature passed an Act that effectively cleared aboriginals from the 
streets. These few points, and countless others summarized elsewhere, paint a picture of strong cohabitation between international sports movements and states that have systematically impugned the human rights of their citizens.

The extent to which contemporary sport federations emphasize an actively humanitarian mission may be tested in economic and organizational terms. First, there is an obvious danger that sports governing bodies will hide behind the rhetoric of 'human rights', 'peace' and 'development', rather than prioritize these missions in hard cash. Comparisons of internal sports budgets are instructive. For example, FIFA's 'humanitarian support fund' has an annual budget of two million Swiss francs (around $f_{907,000)}$ which is distributed to projects selected by the FIFA Finance Committee, chaired by Julio Grondona of Argentina. Among the monies disbursed in 2003 was approximately $£ 30,000$ allocated to HIV/AIDS prevention campaigns at the fifth African under-17 championships in Swaziland. Compare that budget to the $f, 5$ million spent by FIFA's inner circle over six weeks in Paris during the 1998 World Cup finals; or, to the further £1.6 million ear-marked for official 'presents' such as watches and pendants. According to the investigative journalist David Yallop, who unearthed these figures, such profligate sums might be better spent elsewhere:

Imagine an injection of that money into the work being done by an organisation like SOS Children's Villages-a non-denominational organisation founded 45 years ago and now caring directly for some 200,000 disadvantaged children in 125 countries. In 1994 Havelange created a FIFA Youth Fund to help this organisation. Perhaps Sepp Blatter can be publicly shamed into matching the disgusting excesses of Paris with an equivalent amount donated to SOS Children's Villages. ${ }^{10}$

Second, if we turn the spotlight more closely on international sports governing bodies such as the IOC and FIFA, they do not fare particularly well in terms of observing the Declaration through their principles and procedures. For example:

- Article 1 emphasizes that 'all human beings are born free and equal in dignity and rights'. Sports governing bodies tend to ignore egalitarianism by prioritizing elite athletes in resource allocation or bowing to elite interests in the largest sporting nations or institutions.

- Article 3 insists inter alia that all have the right to 'security of person'. Sports clubs and governing bodies have tended to place too little emphasis on protecting the long-term physical wellbeing of athletes. 
- Article 4 insists that 'no one shall be held in slavery or servitude', but sports governing bodies offer little protection to young athletes, especially those in the developing world, who are signed to professional contracts that provide for little more than indentured labour.

- Article 10 states that 'everyone is entitled in full equality to a fair and public hearing by an independent and impartial tribunal', but sport's 'disciplinary procedures' against athletes are often adjudicated on by officials in private.

- Article 18 insists that 'everyone has the right to freedom of thought, conscience and religion', but sports governing bodies traditionally take a harsh stand on those athletes who are deemed to 'bring politics into the stadium'.

- Articles 19-21 relate to the rights of people to express opinions openly, to receive and impart information through any media freely, to associate without hindrance, and to participate in government and other public services. As Chomsky points out, safeguarding these articles is crucial for the full and effective implementation of the Declaration. ${ }^{11}$ However, sports governing bodies habitually restrict freedom of expression by disciplining those who criticize officials and procedures. They restrict mediation of sports to a cartel of broadcasting Trans National Corporations (TNCs). They employ some oppressive crowd control techniques at major sports venues. They countermand participation in the governance of sport, in part through their well-documented, secretive control of information and clientelist political relations.

- Article 23 seeks to protect the working rights of individuals, including membership of trade unions. Sports governing bodies do little at grassroots level to protect the representative rights of professional athletes.

- Article 25 states that all have rights to a 'basic standard of living', including health care and security during unemployment, sickness or old age. Sports governing bodies take no effective institutional steps to protect their professional athletes in this sense.

- Article 26 stipulates that 'everyone has the right to education', which 'shall be directed to the full development of the human personality'. Historically, among young athletes, specialization in sports disciplines with a view towards entering elite levels has invariably led to a serious deficit in other forms of education that would otherwise promote their personal and social development.

- Article 27 entitles all authors of 'artistic production' to have their 'moral and material interests' protected. More commonly, the practices and images of elite athletes have been commodified with comparatively little or no recompense to the sports 'artists' themselves. 
These observations would suggest that international sports federations require to go beyond the vague idealism of their mission statements, and to consider more precisely how their various constitutions and internal procedures accord with the Declaration.

International sports governing bodies must confront the genesis of a 'culture of rights' that operates at popular and legal levels. ${ }^{12}$ This culture is represented institutionally through the growth of critical NGOs, legally through the advent of human rights conventions and charters, informed globally through the Internet, and committed politically to challenging the cultures of secrecy and democratic exclusion within different systems of governance. More broadly, discourses and movements that pursue the globalizing of rights often connect their struggles to the direct challenging of the Western-driven hegemony of neo-liberal globalization. Currently, international sports governing bodies may feel relatively insulated from the concerted criticisms and protests directed by diverse 'anti-globalization' movements towards the World Trade Organization (WTO), the G8, and TNCs (such as sport merchandise companies like Nike and Reebok). However, if one aim of these movements is to institutionalize human rights through sport, then it is a small step politically to refocus these campaigns at the very heart of sports governance. Sports federations that are popularly perceived as corrupt, unaccountable and undemocratic are easy targets for those embodying the new culture of rights.

At a juridical level, as the culture of rights spreads into legal statutes and diplomatic charters, so claims to the autonomy or 'exceptionalism' of sport lose their footing. Already, international sporting bodies have come under pressures from national and international legal systems on the matters of labour markets, illicit drug use, and interpersonal violence. Sports federations might at least anticipate any future moves to enforce human rights conventions more fully by systematic reflection on their own procedures.

\section{Universalism, Relativism and Human Rights}

While it is important to explore the empirical and ethical disjuncture between humanitarian discourses and practices within international sports federations, our discussion still requires to theorize the conception of human rights in more critical terms, with reference to the complex questions of power and meaning. Are seemingly altruistic beliefs in human rights and development merely the velvet gloves that soften the double whammy of Western colonialism and neo-colonialism? Is it possible that 'human rights' is an essentially Western cultural conception that, in truth, carries no universal reach? 
Serge Latouche provides one of the most polemical analyses of how development, human rights and globalization have driven the Westernization of the world. Latouche argues that the Western model is a 'techno-economic machine' that is 'impersonal, soulless, and nowadays masterless'; having 'impressed mankind into its service', it has 'shaken off all human attempts to stop it and now roves the planet'. 'Development' involves simply 'aspiring to the Western model of consumption, the magical power of the white man, the status which went with that way of living'. Thus, the Western 'anti-culture' destroys cultural difference, imposing a triptych of development procedures, namely industrialization, urbanization, and 'nationalitarianism' (the imposition of the nation state as the only acceptable political form in world affairs). NGOs are part of the same 'game', pursuing 'some kind of world domination' by reaching the furthest corners. Latouche does claim that 'uniformity has its limits': other cultures can resist Westernization by retaining 'their own ways of spending leisure time, and their own foods - even in the great metropolises of Africa, Asia or Latin America'. With regard to 'human rights', Latouche falls back on a cultural relativism argument. The West has no universal, rational grounds for challenging or preventing practices in other cultures that it deems to be 'uncivilized' or inhumane. The old and extreme illustration (Western horror of cannibalism) is trotted out to argue that Western rationalism is really founded upon ethnocentricity. ${ }^{13}$

Sport, for Latouche, can only be implicated in this violent invention of the 'Third World'. Sport promotes forms of international record-setting that can entail cultural annexation - for example, no Tibetan ever attempted to climb Everest, but the societies around the Himalayas have since become reorganized to facilitate Western competitors. Sport advocates the performance-directed freedom of individuals to participate, to possibly win, thereby nourishing hopes of deliverance from poverty, but of course, as in the capitalist marketplace, only a handful of participants really succeed. ${ }^{14}$

International sport bodies, as NGOs, may be considered to be involved in building 'world domination' through pushing their little sporting flags into new territories, for example through funding development projects in war-torn African regions where states exist only in theory. Some Third World cultures might produce alternative, more fraternal sporting practices that stand in marked contrast to the aggressive nationalism stoked in Western contexts. But it remains highly problematic to construct categorically different forms of body culture to those institutionalized and inculcated by Western organizations like the IOC or FIFA. 
Post-modern social theorists agree with these arguments on fundamental cultural differences, but can identify greater cultural agency in non- Western societies. Baudrillard, for example, makes an important analytical differentiation between three contemporary global forces: 'globalization' that relates mainly to neo-liberal exchange relations; 'universality' that relates to Enlightenment values such as democracy, human rights and liberty; and 'singularity' that relates to 'languages, cultures, individuals and characters, but also chance, accident, etc. - all that the universal, in keeping with its law, impugns as an exception or anomaly'. Characteristically, Baudrillard reckons that universality has come off worst: 'the concepts of liberty, democracy and human rights cut a very pale figure indeed, being merely the phantoms of a vanished universe'. While globalization is strongly placed, it is not certain to be the winner; singularity provides regular irruptions of conflict and challenge through 'forces which are not only different, but antagonistic and irreducible'. ${ }^{15}$

There are obvious benefits in these general critiques of the interrelations between human rights, development and cultural 'singularity'. They draw potent historical connections between political economic exploitation and specific cultural practices within sports. They help us to maintain a self-critical reflexivity towards the apparent altruism and declared universal benefits of specific aspects of our culture, particularly in relation to human rights and sport.

However, I am concerned that these kinds of cultural relativism regarding human rights harbour three core weaknesses that carry strong practical consequences.

First, in political terms these arguments fail to consider how claims to 'radical cultural difference' may by forwarded by non-Western elites to justify their oppressive powers. For example, are we to ignore the prohibitions, violence and killings surrounding women's football teams in Algeria, on the grounds of 'radical cultural difference?'?

Second, in anthropological terms these arguments freeze, in time and space, other cultures as 'authentic', rather than seeing such cultures as essentially fluid, hybrid and inherently dynamic matrices of meaning. In turn, the culturally relativist arguments imply that, in rejecting the 'development' path, we should return to some notional cultural arrangement without explaining either the social system to be founded as substitute or how future relations with developed nations can be managed. Hence, the harassment of Algerian women's football teams represents one of many cultural and political responses within a dynamic socio-cultural context. If Western development workers and sports-centred NGOs step back from this context, they privilege de facto one set of arguments (opposition to women in sport and public life) over other positions. 
Third, in analytical terms relativist arguments may be advanced to protect the interests of Western elites as well as non-Western autocrats. As Chomsky indicates, there is an odious 'relativism' in the opposition of the United States, for example, towards the full implementation of the Declaration or to the progressive egalitarianism of the United Nations, Educational, Scientific and Cultural Organization (UNESCO). ${ }^{17}$ Similarly, in sport, we need to oppose those Western federations that consider the issue of rights to be more important for 'civilizing' nonWestern societies rather than looking more closely at their own backyard.

This is not to deny that there is a real tension between universalism and rights-protection in the codes of human rights. On one hand, human rights standards may enshrine trans-cultural respect for difference, providing a shelter for minority peoples and practices. On the other hand, more weightily, human rights provide for a selective critique of cultural difference on the basis of 'antirelativist standards'. ${ }^{18}$ Non-Western peoples are clearly cognizant of this dilemma. The most successful strategy towards dealing with the dilemma is not to insist upon the cross-cultural unintelligibility of 'human rights', or to permit elite groups to rebuff enlightened overtures. Instead, indigenous peoples adopt a more practical strategy, in terms of probing human rights standards and international state conventions, to explore spaces that facilitate reform. From the Western perspective, we are still left with the question of how we should articulate clearer sociological and political-philosophical perspectives for relating human rights to senses of cultural difference.

\section{Human Rights, Globalization and Sentimental Education}

To develop a path out of these problems, I think it is helpful to relocate our concern with human rights and 'humankind' more sociologically, before exploring a political-philosophical response to cross-cultural communication. What I propose is to consider Robertson's theorization of human rights relative to globalization, in conjunction with Rorty's conception of Western 'sentimental education'. ${ }^{19}$

Robertson has argued that, despite its language of individualism, the political rise of human rights reflects a stronger 'thematization of humanity' as part of the globalization processes of recent years. For Robertson, 'humankind' is one of four 'elemental reference points', the other three being the individual, the nation-state, and international society. Since the 1870s, the interplay of these reference points has increasingly determined the shape and texture of globalization. Our sharpened understanding of humankind is reflected in contemporary debates regarding not only collective human rights, but also the future of the human species and its 
relationships to the environment. It is further indicated in the thematization of the possibility that the world may somehow be made 'for-itself, rather than simply 'in itself. ${ }^{20}$

This vision is challenged by rival discourses and processes that emphasize untrammelled individual agency in the marketplace, the inalienable sovereignty of nation-states, and the Realpolitik of international diplomacy. Consequently, Robertson identifies four visions of world order that correspond respectively with each of these reference points. Humankind is at the heart of what Robertson classifies as the 'global gemeinschaft 2' model, and this considers global order as achievable only through establishing 'a fully globewide community' that is underpinned by a 'commitment to the communal unity of the human species'. There are two versions of the 'global gemeinschaft 2' model: the first, centralized version advocates the creation of a 'global village' with a 'globewide Durkheimian conscience collective'; the second, decentralized version anticipates a more pluralistic form of world community. ${ }^{21}$

In a prior paper, we have sought to explore how this thematization of humankind may be concretized within the sport of football. ${ }^{22}$ Now, as we have indicated already, there are more than enough counter-examples to show that sport connects to other world visions dominated alternatively by freewheeling individualism, Machiavellian statecraft or turbulent international affairs. Yet we may also note that elements in sport carry both the centralized and decentralized visions of the humankind (global gemeinschaft 2) model. Centrally, the 'global village' is most potently represented through globe-wide mass media coverage of tournaments such as the Olympic Games; and, the 'conscience collective' is envisaged by global sports federations that endeavour to have all competing nations recognize and embody the official rules and ethics within sports. De-centrally, the notion of a 'pluralistic world community' is surely the logical culmination of the 'sincere internationalism' identified by Morgan in the Olympism of Coubertin. For Morgan, Coubertin's goals were akin to those of liberals like Rorty, namely to have people 'soften, but, per impossible, not nullify their ethnocentrism by enlarging their range of acquaintance ... to get them to see that their cherished beliefs and ways of life are only one among many other such beliefs and ways of life'. ${ }^{23}$

The reference to Rorty here is opportune, since his more specific reflections on human rights help us, in my view, to clarify the inter-relations between human rights, cross-cultural dialogue and sport. According to Rorty, we should embrace neither 'cultural relativism' nor its universalist opponent (a pro-Western 'foundationalism'). Rather, in a point that I consider highly compatible with Robertson's view, Rorty insists that we should accept that ours is a 'human rights culture'. 
Rorty insists that it is better to be born into this human rights culture rather than somewhere more 'deprived'. Even the most detestable characters (such as ethnic cleansers or gang rapists) must be viewed as deprived, wherein deprivation is defined by the absence, of Western conditions that enable a sufficiently risk-free existence, and of the adequate thematization of human suffering that we take for granted in the media and the arts.

Our task is generally to make the human rights culture 'more self-conscious and more powerful' by producing 'generations of nice, tolerant, well-off, secure, other-respecting students'. Rorty recommends that these students receive a 'sentimental education', which involves 'manipulating their sentiments in such a way that they imagine themselves in the shoes of the despised and oppressed'. Rorty recognizes that sentimental education has problems in Western culture. We presume that reason is a more powerful force than sentiment. We fear that privileging sentiment politically will entail pinning our hopes on the condescension of 'rich bleeding hearts' like Bill Gates. More practically, 'sentimental education only works on people who can relax long enough to listen'. ${ }^{24}$

Yet, it is the 'long, sad, sentimental story' that works best to convince others that we should care about strangers, even those whose practices are strikingly alien to our own. We must put our cultural sceptics into the shoes of the stranger, to explain how it is 'to be in her situation - to be far from home, among strangers'. Or we might imagine the stranger as within our kin and kind, to suggest she 'might become your daughter-in-law'.

Rorty's argument is not without weaknesses. It does not provide the most systematically reasoned account of how the foundationalism-cultural relativism debate can be concluded rather than evaded. More sociologically, he does not have an adequate account of how 'sentimental education' can co-habit with pre-existing geometries of power. Are not our children, for example, encouraged to become more sentimental towards distant peoples whose religious and diplomatic ties are close to the West? Nevertheless, as Brown notes, Rorty does present the understanding of rights as intrinsic to 'a functioning ethical community' alongside the problems connected to any universalist application of human rights. ${ }^{26}$

I consider Rorty's argument to be particularly worthy of elaboration in the case of sport. Sport arguably provides for cross-cultural encounters with the other, forcing us into bodily and normative dialogue with those that we might find 'irrational' or culturally abominable. Playing sport competitively forces us to think ourselves into the shoes of the opponent. Sport opens domains for advanced forms of sentimental education in regard to human rights. The global 
institutions of sport and their universal legal frameworks allow for the strengthening of our 'shared moral identity which brings us together in a moral community'. ${ }^{27}$ As part of the recreational realm, sport operates in the main within the 'relaxation time' in which sentimental education may work. The pre-event biopics and short documentaries on North African female runners or Middle East football teams should contribute to the establishment of sympathy among those in the West who would otherwise miss thematizations of deprivation.

There are potential problems, of course. Sentimental education might be refracted through mediation to become another form of condescension: that is, the hypostatized melodrama of deprivation, the playing upon sentimentality to narrate 'remarkable' and 'exceptional' stories of individual achievement to the detriment of context and an ethical education. Moreover, the thinking of ourselves into the shoes of others should not be dazzled by commodity fetishism, as we buy ourselves literally into their Nikes or Reeboks. Despite these problems, sport still provides perhaps the most culturally popular medium through which senses of moral obligation towards absolute strangers might be communicated through imagined belonging. We might suggest to our cultural fellows that caring for others is required since they might join our family; more likely, we could suggest that they or their friends might one day join our other cherished institutions, namely our sports teams.

\section{Conclusion}

To sum up, I accept that a significant role has been carved out for sport to play in promoting peace and enhancing human dignity. This does not, however, entail that we must subscribe to the more naïve or evangelical arguments regarding sport's innate goodness. Rather, we must bear in mind the historical relationship of sport to forms of colonialism and neo-colonialism. We must also continue to make critical sociological analyses and judgements regarding the actual 'function' (or otherwise) of sport in achieving societal objectives, such as conflict resolution or social rehabilitation of the traumatized within particular circumstances. Sport can have significant benefits within especially difficult contexts, but only when the 'development' projects are rooted in meaningful dialogue with recipient groups, and when such programmes are accompanied by more direct policies to alleviate disease, hunger, war and forced migration. The governing bodies of the most popular sports can make significant headway by recognizing the rising 'culture of rights', and by seeking to ensure that their own procedures accord closely with human rights standards. 
If we examine the question of human rights and sport at a more theoretical level, then we must turn to discuss the universalism-relativism debate. I have sought to indicate that a cultural relativist approach towards reading human rights has the virtue of highlighting the interconnections between Western imperialism and cultural values. In this context, given some of the weaknesses that are set out above (and these are not exhaustive), I would suggest that the cultural relativism argument is best used heuristically, in exposing each element in the crosscultural transmission of 'rights' discourses and procedures within sport to questions of systematic doubt.

The advanced realities of globalization are such that non-Western cultures have themselves turned to pursuing advantageous spaces within the context of rights discourses. In the globalization process set out by Robertson, the rise of human rights and thematization of 'humankind' gives rise to two particular visions of global community in contrast to other forms of global arrangement. Such particular visions are themselves rather particular to the West. Developing this point, through Rorty, we might consider the West to be the human rights culture', still heavily influenced by Enlightenment values, yet most capable of communicating these mores, not simply through reason, but 'sentimental education'.

Rorty's points therefore remind us that there is much to do at home in strengthening the status of human rights, to educate future generations into recognizing the everyday social significance of these values. The rapid mobility of elite sports athletes, and in particular their transfer across Western sports clubs and nations, has the capacity to demonstrate to us how fateful our membership is of any 'community of fate', whether this relates to a club allegiance or to nationality. In sport, therefore, we must avoid the reduction of 'human rights' to pure sentimentalism, empty rhetoric, and anodyne photo-shoots. Taking human rights seriously necessitates the internal transformation of Western societies and the sports institutions themselves, as well as engaging empathetically, dialogically, with non-Western cultures.

\section{NOTES}

\footnotetext{
${ }^{1}$ The two conferences are Sport en Ontwikkelingssamenwerking, University of Utrecht/Dutch Foreign Affairs Ministry, Utrecht (16 January 1998); and How You Play The Game: Sport and Human Rights, The Human Rights Council of Australia, Bondi, Sydney (1-3 September 1999). ${ }^{2}$ A. Ogi, 'Conference Address', Sport and Development International Conference, Magglingen, Switzerland (16-18 February 2003).

${ }^{3}$ See kwww.redoporte.orgl.

${ }^{4}$ See Gasser and Levinsen, this issue.
} 
${ }^{5}$ R. Giulianotti with G. Armstrong and H. Hognestad, 'Sport and Peace: Playing the Game', paper to the Sport and Development International Conference, Magglingen, Switzerland (16-18 February 2003).

${ }^{6}$ See J. Bale and J. Sang, Kenyan Running (London: Frank Cass, 1994).

${ }^{7}$ J. A. Mangan, The Games Ethic and Imperialism (London and Portland, OR: Frank Cass, 1998) p.18.

${ }^{8}$ See S. Lambrinidis, 'Sport in Conflict Prevention and Peace Promotion', paper to the Sport and Development International Conference, Magglingen, Switzerland (16-18 February 2003).

${ }^{9}$ On the complex relations between the military junta and sport inside Argentina, see E. Archetti, 'Argentina 1978 and After: Military Nationalism, Football Essentialism, and Moral Ambivalence' (unpublished paper, 2003).

${ }^{10}$ See D. Yallop, How They Stole the Game (London: Poetic Products, 1999) pp.295, 296, 311.

${ }^{11}$ See N. Chomsky, 'Recovering Rights: A Crooked Path', in M. J. Gibney (ed.) Globalizing Rights (Oxford: Oxford University Press, 2003) p.76.

${ }^{12}$ On this matter, see the collection M. J. Gibney (ed.) Globalizing Rights (Oxford: Oxford University Press, 2003).

${ }^{13}$ See S. Latouche, The Westernization of the World (Cambridge: Polety Press, 1996) pp. 3, 20, 31, 105.

${ }^{14}$ Latouche (note 13) pp.129-130n; p.45.

${ }^{15} \mathrm{~J}$. Baudrillard, Screened Out, (London: Verso, 2002) pp.158-59.

${ }^{16}$ On women's football in Algeria, see the Guardian (6 November 1999). On women's sport and human rights in Islamic societies see, in particular, A. E. Mayer, Islam and Human Rights: Tradition and Politics, 3rd edn (Boulder, CO: Westview 1999) pp.115-16.

${ }^{17}$ N. Chomsky (note 11) p.55.

${ }^{18} \mathrm{R}$. Niezen, The Origins of Indigenism: Human Rights and the Politics of Identity (Berkeley, CA: University of California Press, 2003) p.143.

${ }^{19}$ See R. Robertson, Globalization: Social Theory and Global Culture (London, 1992); R. Rorty, 'Human Rights, Rationality, and Sentimentality' in S. Shute and S. Hurley (eds.) On Human Rights: The Oxford Amnesty Lectures 1993 (London: Basic Books, 1993).

${ }^{20}$ See R. Robertson (note 19) pp.183, 184.

${ }^{21}$ See R. Robertson (note 19) pp. 78-79. Similarly, Scholte locates the rise of human rights in the wider envisioning of a 'cosmopolitan community'. Echoing Robertson, Scholte suggests that international indications of rising 'universalism' include the greater relevance of 'global village' metaphors. Other trends towards cosmopolitan communitarianism include the Universal Declaration of Human Rights which is adhered to by most states, the establishment of other rights charters by regional bodies in Africa and Europe, the establishment of the International Criminal Court, the success of NGOs such as Amnesty International, the growth of international environmental movements, and the advance of 'cosmopolitan solidarity' on the right of Third World societies to certain levels of 'humane development'. See J. A. Scholte, Globalization: A Critical Introduction (Basingstoke: Palgrave, 2000) pp.178-79.

${ }^{22}$ R. Giulianotti and Roland Robertson, 'Die Globalisierung des Fußballs: 'Glokalisierung', transnationale Konzerne und demokratische Regulierung', in P. Lo“sche, U. Ruge and K. Stolz (eds.) Fussballwelten: Zum Verha"ltnis von Sport, Politik, O " konomie und Gesellschaft (Opladen: Leske and Budrich, 2002).

${ }^{23}$ W. J. Morgan, 'Cosmopolitanism, Olympism, and Nationalism: A Critical Interpretation of Coubertin's Ideal of International Sporting Life', Olympika IV, 88-89.

${ }^{24}$ R. Rorty (note 19) pp.127, 128.

${ }^{25}$ Ibid. pp.133-34.

${ }^{26}$ C. Brown, 'Universal Human Rights: A Critique', in T. Dunne and N. J. Wheeler (eds.) Human Rights in Global Politics (Cambridge: Cambridge University Press, 1999) p.120. 
${ }^{27} \mathrm{R}$. Rorty (note 19) p.117. 